\title{
The Treatment of a Gummy Smile Patient with Laminate Veneers by Reverse Vestibuloplasty: A Case Study
}

\author{
Mustafa Özay Uslu*, Ömer Alperen Kırmızıgül and Mustafa Karaca \\ Department of Periodontology, Inonu University, Turkey
}

Submission: August 17,2017; Published: August 28, 2018

*Corresponding author: Mustafa Özay Uslu, Department of Periodontology, Faculty of Dentistry, Inonu University, 44280, Malatya, Turkey, Tel: +90422 3411100/6254; Fax: +90422 3411107; Email: mustafaozayuslu@hotmail.com

\begin{abstract}
Aesthetically desirable smiles demonstrate a gingival appearance of up to $3 \mathrm{~mm}$. Gummy smile is a clinical condition with gingival display more than $3 \mathrm{~mm}$ which is often unpleasant for the individual. Reverse vestibuloplasty is a traditional surgical approach for the treatment of excessive gingival appearance by repositioning downward of the lips. Reverse vestibuloplasty offers a easy approach for the correction of gummy smile. In this case report, the treatment of gummy smile with reverse vestibuloplasty operation in a female patient with abnormal gingival view, was presented. A systemically healthy female patient was admitted to our clinic with an unesthetic appearance of gingival tissue with anterior teeth. Reverse vestibuloplasty surgery was planned. A two parallel horizontal incisions was made after local anesthesia at the mucogingival junction to alveolar mucosa on the lip, extend from right first molar to the left first molar tooth and the distal parts of incisions was merged. Sharp tissue dissection was made and the tissue was removed. Two horizontal incision lines were connected using simple suttures. The sutures removed after one week. Clinical records was collected at first week, one month and six month later. No complications and no scar were observed after operation. The healing was uneventful. High-level patient satisfaction was achieved.
\end{abstract}

Keywords: Reverse vestibuloplasty; Gummy smile; Aesthetic periodontal surgery

\section{Introduction}

Pleasant smile is the most important part of the beauty of facial aesthetics [1]. The condition of the oral tissues, the gingival outlines, the position of the lips and the symmetry of the teeth form appearing the basis of an aesthetic smile [2]. Ideal smile line is associated with the appearance of $1-2 \mathrm{~mm}$ of gingival tissue with all coronal part of teeth [3]. A gummy smile usually appears when gingival visibility is greater than $3 \mathrm{~mm}$ [4]. Gummy smile is more common in women. In addition, it has been reported that the grade of the gummy smile reduced with age due to decreased muscle tone in the lower and upper lips [5].

Gummy smile is associated with different etiologies. For this reason, it is necessary for the researcher to assess the patient's smile design and to regard the relationship between the patient's teeth, gingiva and lips in a smiling state. Depending on the etiology of the gummy smile treatment methods are crown lenghtening procedures, botulinum toxin injections, intrusion, orthognatic surgeries and reverse vestibuloplasty operation [6-8]. Reverse vestibuloplasty include the removal of a band of maxillary buccal mucosa and subsequently suturing the lip mucosa to the newly formed mucogingival line. The purpose of this approach is to reduce the retraction of the elevator smile muscles (e.g. levator anguli, levator labii superioris, zygomaticus minör and orbicularis oris).

In this case report we aimed to present the outcomes of a gummy smile treatment with reverse vestibuloplasty.

\section{Case Report}

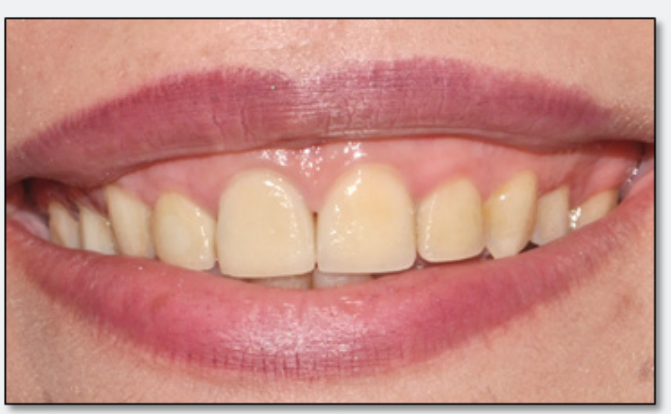

Figure 1: Pre-operative high lip positioned smile.

Systematically healthy 30 years old female patient was admitted with a chief complaint of an abnormal excessive 


\section{Juniper Online Journal of Case Studies}

appearance more than $5 \mathrm{~mm}$ of gingival tissues at anterior teeth (Figure 1). Reverse vestibuloplasty surgery was chosen instead of crown lenghtening procedure because of prosthetic laminate veneers.

A two parallel horizontal incisions was made after local anesthesia at the mucogingival junction to alveolar mucosa on the lip, extend from right first molar to the left first molar tooth and the distal parts of incisions was merged (Figure 2). Sharp dissection was made by scalpel and the reflected half-thickness flap between two incisions was removed (Figure 3).
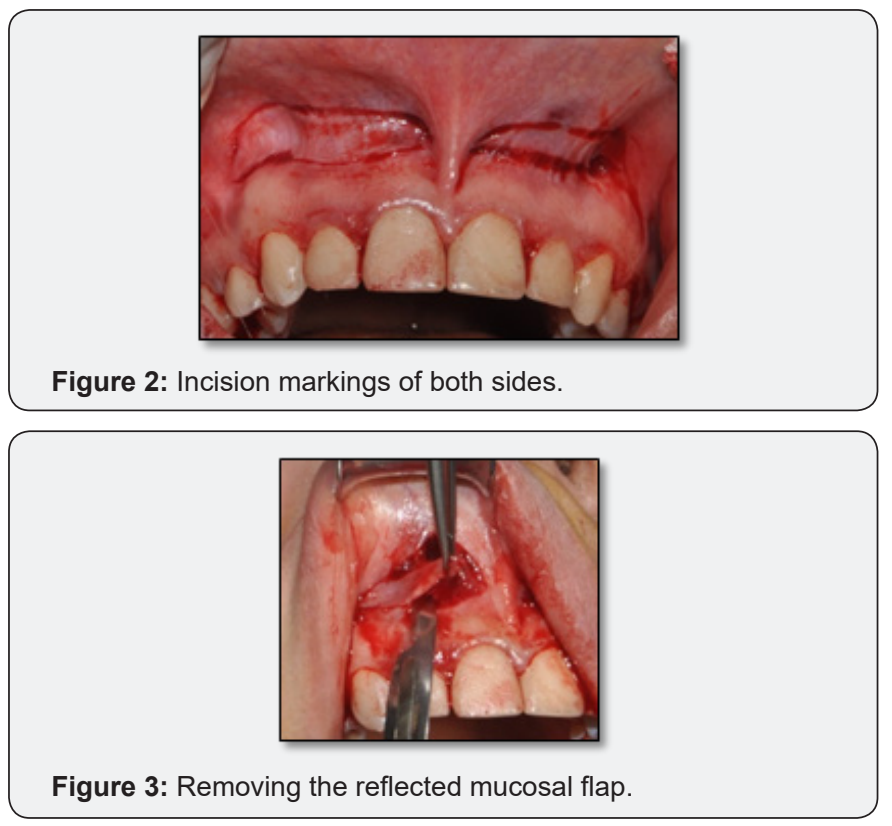

Incision lines of newly formed shortened alveolar mucosa, were connected together with simple sutures (6-0 polyglycolideco-lactide, PGLA, Pegelak, Doğsan) and the tension was eliminated by sling sutures (3-0 PGLA, Doğsan) (Figure 4 \& 5). The surgical area was covered by periodontal dressing (Coepak, GC).
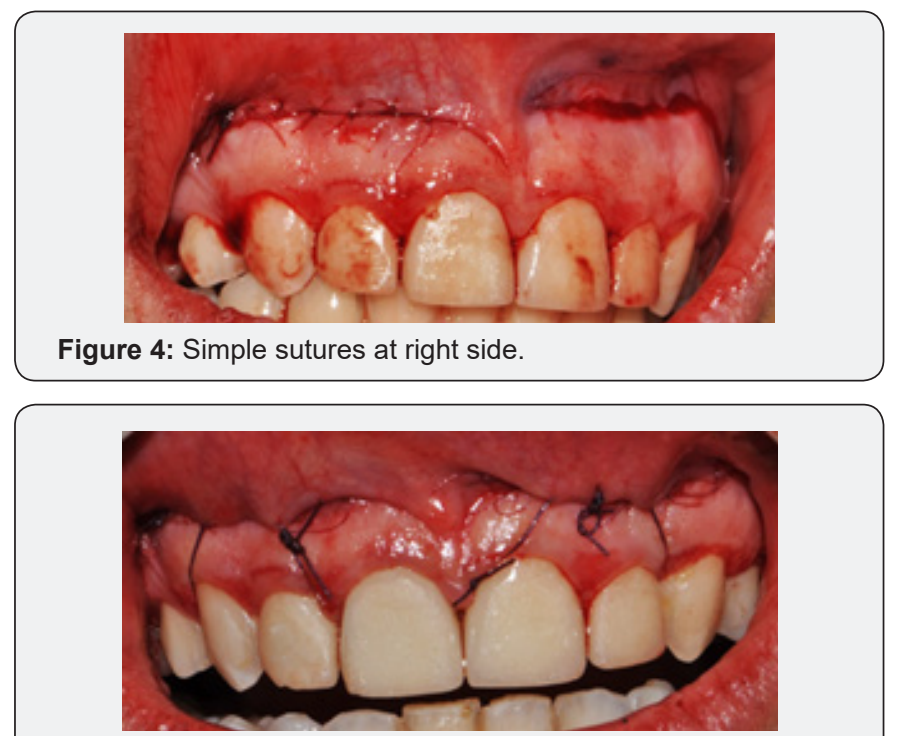

Figure 5: Sling sutures for reducing the tension.
Analgesic and chlorhexidine gluconate mouthrinse was prescribed and a post-op regimen was given. The sutures removed after one week. Clinical parameters was evaulated at 1st week, 1st and 6th month later (Figure 6-8).
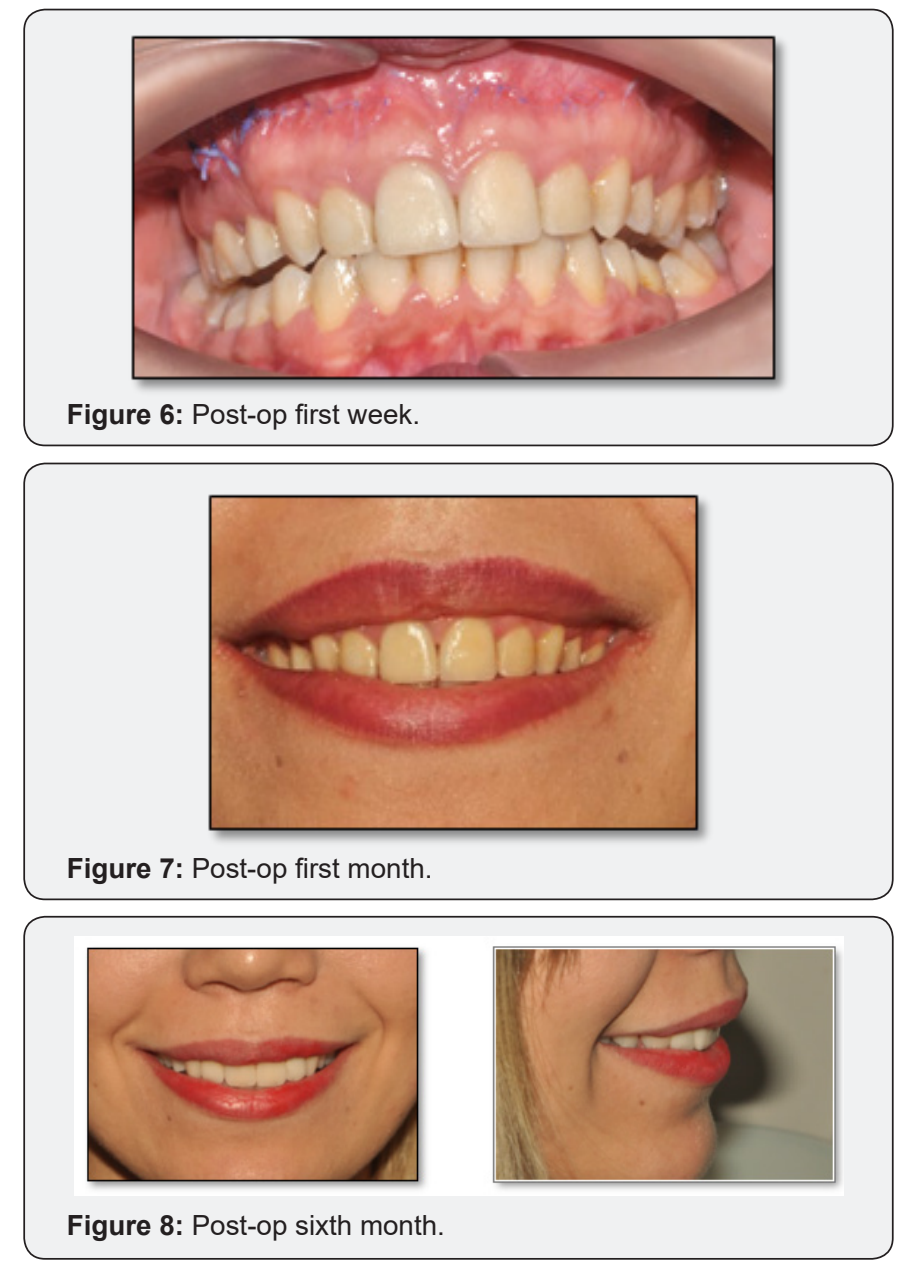

No complications and no scar were observed after surgical operation. The healing was uneventful. The patient recruited an aesthetic smile and there was no relaps.

\section{Discussion}

Excessive gingival appearance known as gummy smile is an aesthetic problem in smile line [3]. Gingivoplasty is usually performed for aesthetic and functional purposes, to increase the crown lengths in the correction of the gummy smile. However, botulinium toxin injections, orthognathic surgical interventions and reverse vestibuloplasty, are among the other treatment options when gingivoplasty is not sufficient [9].

In this case report, we presented a gummy smile patient using with reverse vestibuloplasty method. This procedure contained the retraction of the elevator muscles of the lip (orbicularis oris, levator anguli, levator labii superioris and zygomaticus minor) and a new gingival display was achieved [10]. This method was easy for the patient to accept because it was less invasive than other approaches. When the literature is reviewed, discomfort, postoperative bruising and swelling reported to be minimal. 
Also, the duration of surgery was less time than other surgical procedures [11].

When performing a reverse vestibuloplasty, attention should be paid to surrounding anatomical formations and damage should be avoided. Suturing procedures should be done considering the attached gingiva borderline. If attached gingiva aren't sufficient, flap design, suturing and stabilization are difficulty. Patients with severe skeletal deformities, reverse vestibuloplasty is contraindicated and orthognathic surgery should be considered [7].

\section{Conclusion}

In this case, it was showned that the treatment of some suitable gummy smile cases with reverse vestibuloplasty was very effective treatment modality of and provides stable results.

\section{References}

1. Van der Geld P, Oosterveld P, Schols J, Kuijpers-Jagtman AM (2011) Smile line assessment comparing quantitative measurement and visual estimation. Am J Orthod Dentofacial Orthop 139(2): 174-80.

2. Tawfik OK, Naiem SN, Tawfik LK, Yussif N, Meghil MM, et al. (2018) Lip repositioning with or without myotomy: A randomized clinical trial. J Periodontol 89(7): 815-823.

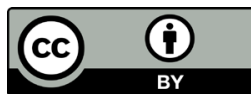

This work is licensed under Creative Commons Attribution 4.0 License DOI: 10.19080/JOJCS.2018.08.555737
3. Zawawi KH, Malki GA, Al-Zahrani MS, Alkhiary YM (2013) Effect of lip position and gingival display on smile and esthetics as perceived by college students with different educational backgrounds. Clin Cosmet Investig Dent 5: 77-80.

4. Spear FM, Kokich VG (2007) A multidisciplinary approach to esthetic dentistry. Dent Clin North Am 51(2): 487-505.

5. Desai S, Upadhyay M, Nanda R (2009) Dynamic smile analysis: changes with age. Am J Orthod Dentofacial Orthop 136(3) : 310e1-310e10.

6. Mantovani MB, Souza EC, Marson FC, Corrêa GO, Progiante PS, et al (2016) Use of modified lip repositioning technique associated with esthetic crown lengthening for treatment of excessive gingival display: A case report of multiple etiologies. Journal of J Indian Soc Periodontol 20(1): 82-87.

7. Jananni M, Sivaramakrishnan M, Libby TJ (2014) Surgical correction of excessive gingival display in class I vertical maxillary excess: Mucosal strip technique. J Nat Sci Biol Med 5(2): 494-498.

8. Polo M (2008) Botulinum toxin type A (Botox) for the neuromuscular correction of excessive gingival display on smiling (gummy smile). Am J Orthod Dentofacial Orthop 133(2): 195-203.

9. Magid KS, Strauss RA (2007) Laser use for esthetic soft tissue modification. Dent Clin North Am 51(2): 525-545.

10. Litton C, Fournier P (1979) Simple surgical correction of the gummy smile. Plast Reconstr Surg 63(3): 372-373.

11. Kamer FM (1979) Plastic surgery: Practical suggestions on facial plastic surgery: Smile surgery. The Laryngoscope 89(9): 1528-1533.

\section{Your next submission with Juniper Publishers will reach you the below assets}

- Quality Editorial service

- Swift Peer Review

- Reprints availability

- E-prints Service

- Manuscript Podcast for convenient understanding

- Global attainment for your research

- Manuscript accessibility in different formats

( Pdf, E-pub, Full Text, Audio)

- Unceasing customer service

Track the below URL for one-step submission https://juniperpublishers.com/online-submission.php 